\title{
Necessary and Luxury Loanwords in British, American, and Georgian Online Newspapers and Magazines
}

\author{
Maia Gurgenidze \\ Ivane Javakhishvili Tbilisi State University, Tbilisi, Georgia
}

\begin{abstract}
The perception and use of loanwords in most literature, more specifically, online newspapers and magazines based on British, American, and Georgian media discourse, focus on the origin and the fundamental development of language content and the essentiality of luxury and necessary loanwords. Due to the fact that most magazines are created with an intention of convincing readers of various ideologies, most linguists would consider the use of loanwords to give a comprehensive presentation of ideas. Incorporating English loanwords is not only a requisite tool for integrating and addressing the cultural differences between various communities across the globe, but also acts as a bridge that fills the conceptual gaps that exist in various languages. This is no longer the job of a linguist, because there are many other ways through which the people of a particular country can adopt a loanword (e.g., social media). Also, it enriches the recipient language and puts its citizens up to date with the latest developments and inventions.
\end{abstract}

Keywords: loanwords, content, tool, recipient, development, intention, ideology

\section{Introduction}

Many distinguished linguists define the concept of English loanwords as adopting the content and elements of specific English words by another language (Danesi \& Rocci, 2009). The origin and the foundational development of the essence of a particular language with the necessity of luxury and necessary loanwords are prime factors affecting the creation of the perceptions and the use of this kind of words in the American and British media discourse, which is based on the literature used in online newspapers and magazines. Yelenevskaya (2008) observed that the process of the linguistic development and evolution reinforces the borrowing of certain loanwords by different languages. Internal and external concerns arise as a result of the interaction between different languages. The reason behind the borrowing of loanwords can be explained by the need of defining and explaining the development of economic, political, and cultural spheres. The discourse of native speakers of a particular language raises a concern on the linguistic variation caused by borrowing of loanwords by another language (Verspoor, De Bot, \& Van Rein, 2011).

\section{The Application of Loanwords}

The integration of loanwords in a particular language supports the development of the mainstream media (Svartvik \& Leech, 2006). The prime phenomenon behind the application of an English loanword in most online magazines and newspapers is language. Nevertheless, the use of English loanwords depends on the

Maia Gurgenidze, Ph.D., Assistant Professor, Ivane Javakhishvili Tbilisi State University. 
validity of an online newspaper and magazine (Rosenhouse \& Kowner, 2008). The application of English loanwords is a matter of necessity of a country's online magazines and newspapers, despite the fact that various linguists have emphasised much on the creation of lexical processes, which would encompass the implementation of numerous lexical-semantic systems in a modern language. Moreover, as the world becomes more interlinked and connected, specifically the English-speaking world, it becomes more appealing platform for facilitating the use of lexical borrowings (Daulton, 2008).

The presence of English loanwords in most online magazines and newspapers does not jeopardize political opinions and the importance of cultural differences (Gentsch, 2004). The use of loanwords can be promoted employing marketing techniques and strategic planning (Rosenhouse \& Kowner, 2008). Another concern about using loanwords is that it can get a different meaning by another language. The use of loanwords is understood as an attempt to adapt the patterns of one language into another (Phillipson, 2009). However, borrowing loanwords is essential for the development of a particular language. This idea is quite actual and valid since it articulates the fact that borrowing English words is much easier than creating a word. The use of English loanwords in most online newspapers and magazines not only establishes a platform for enriching recipient languages, but also reduces the intellectual efforts needed to come up with new words (Danesi \& Rocci, 2009).

Most linguists, in determining the authenticity of English borrowing, have brought the idea of Anglicism into account. Most notably, Anglicism is presented as a modality or rather as an idiom that identifies the credibility of English in its content and form. The consideration of Anglicism could help address matters pertaining to spelling, articulation, and pronunciation of words, and the general morphological content of loanwords (Pennycook, 2001). In addition, Anglicism is fundamentally perceived and conceptualized as a modern strategy in defining language vocabulary.

Be that as it may, the notion of loanwords is conceptualized as a metaphor since it considers the actual borrowing of the elements of the source language and applying them in the target language. In as much as a variety of loanword aspects are considered in the context of numerous languages, the power and the prestige of the source language remains unaltered (Danesi \& Rocci, 2009). Realistically, the incorporation of foreign languages in a particular language does not need to consider defining loanwords if the recipient society considers them as major development pillars in the history of its language. Additionally, if foreign languages are widely used and conventionalized, the recipient society definitely considers them an integral part of their English loanword. According to Daulton (2008), more specifically in view of the linguistic mainstream, the use of English loanwords is established and recognized as code-switching where the pronunciation and the morphological content of words follow the idealistic order of the donor language.

\section{The Use of Loanwords Online}

Code-switching is generally used in the cases where individuals in bilingual or multilingual societies express the ideas, which require attention on its meaning. On the other hand, the expression of English loanwords is carried out through the process of lexical transformation (Rosenhouse \& Kowner, 2008). The underlying objective for incorporating loanwords in the linguistic mainstream is to bridge the conceptual gaps that exist in most languages. These objectives may consist of linguistic and extra-linguistic circumstances. An example can be the naming of new objects and processes in the field of science and technology (Pennycook, 2001). This perspective is based on the terminology of lexical innovation. The similarity of this phenomenon in several different languages clearly explains the significance of considering English loanwords in most 
marketing magazines. According to Pavlenko (2010) it is necessary to come up with several synonyms of a particular word in order to outline the essentiality of the ways of expression and the consideration of borrowing English words in different contexts.

With regards to language economization, brevity has been a major factor in reinforcing the simplicity of the English language. This idea is based on prestige and on the sense of self-actualization. Hence, humanity will definitely feel competent and proud when they frequently adopt English loanwords (Gentsch, 2004). The fundamental drive behind boosting the popularity of fashion has played a central role in updating the trend of urban speech conceptualization. The perception of the application of English loanwords has been actualized by societies as a way of playing with the language and expressing the trend and development of fashion. This technique has been on the forefront in facilitating the essentiality of literary languages (Phillipson, 2009).

The sole objective of borrowing various aspects and elements of languages depends on the needs of the people, who are in line with the norms, which dictate a prestigious standard of life. An idealistic purpose for loanwords is quite explicit in helping the speaker develop an adequate understanding and familiarity with the new elements and content in the English language (Svartvik \& Leech, 2006). As a result, it is worth noting that considering borrowing English loanwords is purely based on the ideological notion of linguistics. On the same line, this can be illustrated by both linguistic and extra-linguistic cases, particularly in filling the lexical gap between different languages as observed by Phillipson (2009). English loanwords have always been articulated considering historical and socio-economic aspects. Many magazines and online newspapers, specifically written with the intention of advertising the economic development of most nations, emphasize the use of loanwords to persuade the society to develop a positive understanding towards the essentiality of borrowing foreign words in the competitive environment.

The use of loanwords is the central factor in promoting the idea of literacy and the use of codified language, as well as the perception of erudition and dislike of a native language. According to Pavlenko (2010), the globalizing character of linguistics and its effect on the success and modernity of the competitive countries can explain the expressive application of English loanwords in different contexts. However, the use of English loanwords can also be explained by the unconscious modality of a speaker (Pennycook, 2001). The key purpose behind borrowing loanwords by different languages is to lexically enrich this particular language. Previous studies in the field of linguistics argue that the idea of globalization has taken a centre stage in strengthening the use of loanwords in some countries. However, the effectiveness of luxury and necessary loanwords may not be the same in online newspapers and magazines (Danesi \& Rocci, 2009).

The analysis regarding the conceptualization of luxury loanwords is more extensive in online newspapers than in published magazines, because, in the latter, the active usage of necessary and luxury English loanwords is fully conceptualized. According to Verspoor et al. (2011), several nations have resisted the influence of English loanwords in their native languages. Linguists in many nations argue that borrowing English loanwords in writing online newspapers and magazines distorts the credibility of the media discourse since they do not incorporate the aspects and elements of the native languages. Hence, the need to substitute English loanwords with the content of the native languages is inevitable and needs to be accorded requisite attention (Phillipson, 2009). The consideration of foreign languages in establishing objective opinions in the linguistic discourse has not only helped avert the concern of barbarization but has also played an essential role in discouraging the excessive usage of irrelevant ideologies in most recipient languages.

Due to the fact that most magazines are created with an intention of convincing the readers about various 
ideologies, most linguists would consider the use of loanwords as a way of comprehensively present ideas. As a result, readers of most magazines would fully understand what is required of them (Daulton, 2008). The adoption of English loanwords represents the essentiality of linguists in the ever-changing economic and cultural differences in third world countries.

\section{Conclusion}

In conclusion, it can be stated that it is necessary to use loanwords in online newspapers and magazines and this has to be addressed and discussed by linguists with an appropriate depth. The use of loanwords has many advantages and one of them is that it develops the personality and performance of linguists. Future studies have to concentrate on developing the use of lexical borrowings, because it plays an influential role in establishing an ideal platform for learning different languages and linguistics. Future researchers and linguists need to be in the forefront in championing the idea that incorporating English loanwords is not only a requisite tool for integrating and addressing the cultural differences for several communities across the globe, but also acts as a bridge that spans the conceptual gaps that exist in various languages. The most important advantage of borrowing loanwords in a particular language is that it helps the recipient country to be up to date with the economic, political, and technological (along with other) developments of the world. As it was stated, it is difficult to create a new word and sometimes the words that already exist, explain the new phenomena perfectly. Thus, its use enriches the recipient language and brings its citizens up to date with the new inventions and processes.

\section{References}

Danesi, M., \& Rocci, A. (2009). Global linguistics: An introduction. Berlin: Mouton de Gruyter.

Daulton, F. E. (2008). Japan's built-in lexicon of English-based loanwords. Clevedon: Multilingual Matters.

Gentsch, K. (2004). English borrowings in German newspaper language: Motivations, frequencies, and types, on the basis of the Frankfurter Allgemeine Zeitung, Muenchner Merkur, and Bild. (Ph.D. thesis, Swarthmore College).

Kargaonkar, K., \& Lori, D. W. (2008). A multivariate analysis of web usage. Journal of Advertising, 39(2).

Kassin, S. (2006). Psychology in modules. Upper Saddle River, New Jersey: Pearson Education, Inc.

Korgaonkar, K., \& Lori, D. W. (2009). A multivariate analysis of web usage. Journal of Advertising Research, 39(2). Upper Saddle River, New Jersey: Prentice Hall.

Nordenstreng, K. (2005). Comments on gratifications research in broadcasting. Public Opinion Quarterly, 34. Upper Saddle River, New Jersey: Prentice Hall.

Pavlenko, A. (2010). Linguistic landscape of Kyiv, Ukraine: A diachronic study. In E. Shohamy, E. Ben Rafael and C. Barni (Eds.), Linguistic landscape in the city (pp. 133-152). Clevedon: Multilingual Matters.

Pennycook, A. (2001). English in the world/the world in English. In A. Burns and C. Coffin (Eds.), Analysing English in a global context: A reader (pp. 78-92). London: Routledge in association with Macquarie University and the Open University.

Peter, S. (2009). Identifying document topics using the Internet for twitter category network. Web Intelli. and Agent Sys.

Phillipson, R. (2009). Linguistic imperialism continued. New York: Routledge.

Roe, K., \& Music, K. (2009). Listening patterns and motivations. Communication Research, 12(3). Oxford: Oxford University Press.

Rosenhouse, J., \& Kowner, R. (2008). Globally speaking: Motives for adopting English vocabulary in other languages. Clevedon: Multilingual Matters.

Steven, B. (2009). Natural language processing with Python. O’Reilly Media, Inc.

Svartvik, J., \& Leech, G. N. (2006). English: One tongue, many voices. Basingstoke: Palgrave Macmillan.

Verspoor, M. H., De Bot, K., \& Van Rein, E. (2011). English as a foreign language. The role of out-of-school language input. In A. De Hower and A. Wilton (Eds.), English in Europe today: Socio-cultural and educational perspectives. Amsterdam: John Benjamins. 
Yelenevskaya, M. (2008). Russian: From socialist realism to reality show. In J. Rosenhouse and R. Kowner (Eds.), Globally speaking: Motives for adopting English vocabulary in other languages (pp. 98-120). Clevedon: Multilingual Matters.

Yoav, F., \& Llew, M. (2006). The alternating decision tree learning algorithm. In ICML '99: Proceedings of the Sixteenth International Conference on Machine Learning. San Francisco: Morgan Kaufmann Publishers Inc. 